\title{
Teachers' Attitudes towards Conducting Interlanguage Analysis to Prepare Better Instructions
}

\author{
Morganna, $\mathbf{R}^{1}$ \\ ${ }^{1}$ Graduate School of English Education Department, The Faculty of Teacher Training and \\ Education, Sebelas Maret University, Surakarta, Indonesia \\ Corresponding email: ruly_morganna@gmail.com
}

\begin{abstract}
This study focused on investigating attitudes had by English teachers in Indonesia towards preparing more qualified English instructions for further teaching processes through doing interlanguage analysis on the basis of students' current competence of using English. The term competence in this study referred to students' communicative competence. This study was conducted qualitatively to probe into the participants' attitudes on doing interlanguage analysis, in that they were ten English teachers having been teaching English in Indonesian schools with varied experiences. They were selected purposively under considerations that they were experienced and taking graduate program, so that they were sufficiently familiar with this study issues, and it could be guaranteed that they managed to furnish the clarity of this study data. The data of this study were obtained through disseminating semi-structured questionnaire to the participants, and then pursuing the data was also undertaken to reach the clarity. The results indicated that despite some particular and situational constraints, all participants shared their positive attitude towards conducting interlanguage analysis on students' English competence from the viewpoints of affection, behavior, and cognition. This study was essential since it could contribute on being one of references for English teachers to improve the quality of further instructions. This study was only delimited on the area of attitude. More researches were also expected to be conducted especially on the area of interlanguage analysis application to reveal more valuable and contributive knowledge in this issue.
\end{abstract}

Keywords: Communicative competence; English instruction; Interlanguage analysis; Teachers' attitude

DOI: http://dx.doi.org/10.20961/ijpte.v1i2.15080 


\section{INTRODUCTION}

In teaching and learning context of English as a foreign language, interlanguage analysis plays a role as one of means of formative assessment in that its function is to give feedback to the learners as the reflection of their development and to the teacher as the reflection for preparing more effective teaching (Brown, 2004). Regularly carrying out the formative assessment is crucially required to be maintained for reflective teaching in the trend of $21^{\text {st }}$ century learning (Greenwald, 2013). If concentrated on the teacher's aspect as the learning facilitator, interlanguage analysis is useful for planning more qualified further instructions viewed from either designing appropriate English learning materials, planning the appropriate teaching strategies that fit students current competence to use English (IEAB, 2007), or getting the appropriate oriented focus on the basis of students' needs which should be emphasized in classroom instructions.

The term Interlanguage refers to a language system which learners have while learning a second language in that this language is different from learners' native language and their target language by virtue of that it takes place between L1 and L2. This language system is fossilized when it is eventually unchangeably produced by learners. Interlanguge is identical to neither one produced by the native speaker of the target language, nor one as the precise translation form L1 to L2 (Selinker, 1972). Nemser (1969) uses the term "approximative system" to portray interlanguage as a systematic self-contained language system owned by learners. The systematicity represents the systematic behavior of non-native language (Sharwood, 1994). Learners' interlanguage keeps developing as it successfully passes the stages of language acquisition (Corder, 1967). Concerning with its essence that interlanguage possesses its own system, Adjemian (1976) postulates that there are four characteristics of interlanguage involving systematicity, permeability, dynamicity, and fossilization.

The systematicity engages in linguistics elements such as lexical, phonology, morphology, syntax, pragmatics and etc. At a certain phase of progress, students' linguistic competence becomes systematic as an interlanguage (Troike, 2006). The system of interlanguage is permeable due to being naturally constructed on the basis of influences obtained from both the native and target languages. Accordingly, its permeability helps and leads into the existence of a unique system (Yip, 1995). With its uniqueness, the system of interlanguage is developing as learners are in the progress of learning and pass the milestone of language acquisition (Troike, 2006). The system will fossilize when it is not dynamic and permeable any longer (Selinker, 1988). The fossilization can indicate learners' success of learning if it takes place once they have passed a particular phase of second language acquisition milestone, and it also refers to the learners' errors when their interlanguage system fossilizes before a certain phase of language acquisition is achieved (Ellis, 2004).

The insights about interlanguage are developing in line with the development of researches centralized on it. The progress leads into the change of several aspects which should be viewed when an English teacher would like to analyze learners' interlanguage development. In accordance with doing interlanguage analysis, its 
aspects are viewed from not only students' grammatical competence but also the entire areas of communicative competence (Tarone, 2006; P21, 2011).

The term communicative competence is theorized into a variety of views. Communicative competence is wider than a mere competence of grammar where the competence is also connected to the ability of utilizing grammatical competence in various communicative situations (Hymes, 1972). Communicative competence refers to knowledge of linguistics and sociolinguistics convention (Widdowson, 1983). Communicative competence ranges into knowledge and skill which are systematically applied for communication. Knowledge encompasses grammatical principal, the means of using language contextually and functionally, and the means of applying discourse principle. Furthermore, skill refers to the procedure of knowledge use in real communications (Canale and Swain, 1980; Canale, 1983). Communicative competence keeps progressing and can be observed, strengthened and evaluated through learners' performance of interlanguage. This competence becomes naturally dynamic, more interpersonal and relative in accordance with the context of communication (Savigon, 1972, 1983; Canale and Swain, 1980; Skehan, 1995, 1998; Bahman and Palmer, 1996).

There have been encountered three popular models of communicative competence so that the areas of communicative competence can be identified and subsequently become the crucial areas or objects for analyzing learners' interlanguage. Canale's model (1983) offers four areas of communicative competence that encompass grammatical, sociolinguistics, discourse, and strategic competences. Bahman \& Palmer (1996) present their model whose areas involve grammatical, textual, functional, and sociolinguistics knowledge. Another model simplifies the previous areas into language, pragmatics including discourse and functional, and sociolinguistics competences (CEF, 2001). If critically analyzed and compared from the relatedness of the three models, despite some differences the models have several fundamental areas of communicative competence which are related to one another. They are the competence of grammar, sociolinguistics, discourse, and strategies of communication. These areas can be the objects of doing interanguage analysis since they are observable as learners' progress of language use and can be evaluated for gaining learners' current ability so that the English teacher can prepare further teaching relevant to learners' existing ability.

The viewpoint of conducting interlanguage analysis is different from contrastive analysis known as the strategy to prepare second or foreign language learning materials with comparing through a parallel description between learners' L1 and L2 (Lado, 1957; Wardhaugh, 1970; Fisiak, 1981), and error analysis known as the study which analyzes learners' second language systems from the error aspects of learners' language production to see their current competence of language use and to prepare further both learning materials and teaching strategies (Troike, 2006; James, 1998). Interlanguage analysis is carried out from the perspective that the development of learners' language system, interlanguage, should be viewed from not only errors but also non-errors or the success of their language use on the basis of communicative competence (Mizuno, 1988). Accordingly, conducting interlanguage analysis is analyzing learners' progress of language use with considering the areas of communicative competence as the basis of analysis under 
the perspective of analyzing both errors and non-errors so that the teacher has the data of learners' current competences as the milestone of preparing relevant and appropriate further materials, teaching strategies, and teaching orientation.

Doing interlanguage analysis is really useful and important to be regularly applied by English teacher towards students' language development, interlanguage development. The usefulness of interlanguage analysis takes place as one of strategies of formative assessment carried out by the English teacher (Alvares, et al, 2014). The practice of formative assessment towards learners' language competence furnishes the opportunities for the English teacher to organize the subject matter, orients novel roles and responsibilities, and evaluates the teaching practice (Abedi \& Linquanti, 2012).

The means of doing interlanguage analysis initiates from taking the data of students communicative competence in the form of both the spoken and written data. Frith (1978) offers an example of guidance which can practically be carried out by the teacher in doing interlanguage analysis with tasking students to have a free conversation or to produce a free written text, recording natural learners' oral and written data, asking students to provide both oral and written data in a sufficient length so that the analysis can be conceivably done, collecting both spoken and written data through several techniques, and analyzing the data on the basis of the required areas. Since the biggest areas of language ability are included in learners' communicative competence, it can later be the primary consideration for analysis. In addition, gaining learners' interlanguage data for further being analyzed can also be committed by utilizing portfolio (Pierce and O'Malley, 1992; Geogiou \& Pavlou, 2003; Pallotti \& Peloso (2008).

By virtue of interlanguage analysis role which is as one of the strategies of doing formative assessment, the data of students communicative competence in producing interlanguage can be collected in a variety of techniques for later being analyzed by the teacher. Rea-Dickins, (2001); Genesee et al (2006) recommend for utilizing several techniques such as portfolios, journals, observational checklists, peer assessment, assessment dialogues, and etc. Basically, the more creative the English teacher is in doing interlanguage analysis as a formative assessment, the more probable techniques that he can employ to obtain the data of students' current competences are found.

After obtaining the data representing learners' current competences, the teacher needs to analyze them from classifying the errors and non-errors. Both of the classified conditions are useful to conclude the extent of learners' development. From the errors, the teacher can prepare further learning materials, instructional strategies, and teaching focused orientation which are well planned. In addition, from the non-errors, the teacher can prepare further new materials at the next stage of the learners 'current success, continuous instructional strategies that are potential to maintain their success, and orienting the next materials with maintaining the previous ways of orienting teaching processes as ones yielding to students' success. Conducting interlanguage analysis will promote the teacher to capably make effective decision upon providing further effective and more qualified instructions. 
Besides the essence and the usefulness of interlaguage analysis, to capably implement this activity as a good formative assessment to prepare a better further instruction, it is considered important to view the English teachers' attitude towards interlanguage analysis. It is because attitude becomes the indicator which promotes an action. Attitude is defined as the way a person gives reaction to his circle (Ajzen \& Fishbein, 1977). This reaction then represents his predisposition or tendency towards giving actions to the object attitude. This reaction goes under reflexively connective evaluations generated from feeling, behavior, and belief (Baron \& Byrne, 1984; Malhotra, 2005). The attitude lies as the initiation of making decision because someone who has an attitude towards something will eventually decide what he is going to do as the reaction toward that thing.

In general studies, someone's attitude can be investigated through several ways as constructed into several models of attitude identification. They are such as expectancy value model by Rosenberg (1956) in that it ranges into the expectancy of belief and value or affect connected to the belief. Fishbein (1963) offers a model called multiattribute measurement model which portrays that attitude consists of affect to represent the belief and evaluation to an object. Calder and Luts (1972) present attitude within two components involving affective component (favorableness) and cognitive component (probability). Continuously, Spooncer (1992) offers his model which divides attitude into feelings, beliefs, and behavior. The one which is the most popularly used as to investigate attitude is that offered by Eagly and Chaiken (1998) namely ABC model in which attitude has three domains such as affective, behavior, and cognitive.

Concerning with the teacher's attitudes towards interlanguage analysis, there have been encountered several previous studies which investigate the attitude towards the analysis of learners' language. However they mostly focus on errors of students' interlanguage and viewing attitude either from the teacher or the students with different study purposes such as ones conducted by (Schulz, 1996; Fang \& Xue-mei, 2007; Ryan, 2012; Tomczyk, 2013).

In this study, the learners' language, interlanguage, is viewed from not only the errors but also the non-errors. Furthermore, the attitude is viewed only from the teacher's side which is investigated with using $\mathrm{ABC}$ model containing affective, behavior, and cognitive domain. The focus of this study is on investigating Indonesian English teachers' attitudes towards doing interlanguage analysis on students' language where the analysis itself plays a role as one of strategies in doing formative assessment so that the teacher can prepare a better, more effective, and more qualified further instructions.

Considering this condition, it is clear that carrying out interlanguage analysis is really crucial as one of strategies for gaining teaching reflection that is recommended in the $21^{\text {st }}$ century teaching. Related to what has been portrayed in which there is a need for the English teacher to undertake interlanguage analysis as teaching reflection for planning more effective and qualified instructions, the teacher is needed to have positive attitude of doing interlanguage analysis so that this action can regularly be applied for attaining the success of teaching which meaningfully supports students' language acquisition. Therefore, this study 
focuses on investigating English teachers' attitude towards doing interlanguge analysis for preparing better further instructions.

\section{METHOD}

In this study, the data were qualitatively collected through questionnaire given to ten Indonesian English teachers who have varied experiences. The English teachers, the participants in this study, were purposively selected in accordance with the criterion that they had been familiar with the technical terms related to the issues of interlanguage, communicative competence, and English instructions since they were graduate students and had been dealing with these terms. The number of participants was determined by the completeness of expected data. The required data had been obtained from engaging ten participants. Their familiarity to these terms was essential for them to capably furnish conceivable data of this study. The questionnaire was designed on the basis of attitude model offered by Eagly and Chaiken (1998) namely ABC model. The three domains of ABC model (affective, behavior, and cognitive) were made as the three themes where several items grounded into the areas of communicative competence as to represent learners' interlanguage were constructed.

\section{RESULT AND DISCUSSION}

This study encountered several findings which extended on the orientation relevant to the study focus regarding English teachers' attitudes towards doing interlanguage analysis for preparing more qualified English instructions. The data were split into three major categories of attitude adopted from the attitude model by (Eagly \& Chaiken, 1998), in that those categories ranged into affective, behavior, and cognitive. Several related sub-categories under each of the major categories had also been found within the data. More specific points were also found within the sub-categories.

\section{Affective Category}

All participants had positive affection regarding interlanguage analysis as represented by their feeling and emotion which are devoted to their interest.

\section{Eagerness to Conduct Interlanguage Analysis}

Some participants had interest in conducting interlanguage analysis since they would like to endeavor to give students the learning process which was on the basis of students' needs including competences such as linguistics competence, discourse competence, and communication strategy competence: "I am interested in doing interlanguage analysis so that I can plan my teaching convenient with my students' competences" (Teacher 3). They placed interlanguage analysis as one of 
means of applying formative assessment: "I think interlanguage analysis can give feedback to my students for reflecting to their competences" (Teacher 6). Formative assessment was potential to give feedback to students regarding how far students' development had been going on.

Some participants were interested in applying interlanguage analysis towards students' English competences by virtue of the needs to possess some bases for preparing further teaching. It is such as one of statements mentioned by one of participants: "with knowing my students' English competences as the result of applying interlanguage analysis, I can then prepare a good concept of next teaching process” (Teacher 1).

\section{Behavior Category}

All participants also had positive behavior to do interlanguage analysis towards students' English competences. However there were several challenging cases which impeded them to regularly manage to conduct interlanguage analysis.

\section{The Possibility of Doing Interlanguage Analysis}

Participants of this study shared their views that interlanguage analysis was possible to be conducted with giving students writing and oral assessment: "yes, with giving them writing and spoken test" (Teacher 2), and with furnishing them learning activities such as assigning them to communicate in group work and pair work: "it can be while tasking them to have discussion with their friends" (Teacher 7). These activities promoted the teachers in order to capably analyze students' linguistics competence, discourse competence, and strategic competence.

However, other participants also complained that to capably conduct intelanguage analysis it must be on the basis of time availability: "if I reflect to my experience, I often lack of time to completely do interlanguage analysis" (Teacher 5). This situation generated a consequence that interlanguage analysis could not be undertaken in every meeting: "because of time availability, I don't do interlanguage analysis in every meeting" (teacher 7). Furthermore, some participants also emphasized that other tasks, rather than doing interlanguage analysis which should also be completed by them as the teachers, were quite a lot so that they needed lots of time to be accomplished: "I also have other duties as given by the curriculum adopted by the school where I teach. These duties also preoccupy my focus" (Teacher 9). The consistence of doing interlanguge analysis could also be related to the number of duties whose the participants were in charged with in accordance with the curriculum. 


\section{Ability to Do Interlanguage Analysis}

Interlanguage analysis was capable to be undertaken with utilizing a variety of teaching and assessment media as the bridge to trigger the output in the form of students' English competence: "I often use some tools of teaching and assessment to manage to do interlanguage analysis" (Teacher 2). The output was made to be the object of interlanguage analysis in which subsequently the analysis result was employed as the basis of preparing further relevant learning materials and further teaching strategies that fitted students' needs.

\section{Difficulties and the Influential Factor to Conduct Interlanguage Analysis}

Some participants acknowledged that for a particular area of analysis like sociolinguistics competence, interlanguage analysis was difficult to be carried out due to teachers' related knowledge and understanding which were still limited. This condition was such as to analyze and interpret whether idioms or dialects used by students have been included in the standard of intelligibility or not. One of participants shared her view: "I am difficult to assess whether particular idioms commonly used by my students are really contextually correct or not if compared to the occasion when those idioms are spoken" (Teacher 10).

Technically, the limitation of English output produced by students could occasionally impede the success of doing interlanguage analysis as well. A participant complained: "sometimes my students are nervous to talk in English" (Teacher 4). On the other hand, the teachers could not insist to force students to produce their English output because there would be a silent period before they were capable of producing English output relevant to the current materials that they were learning.

Doing interlanguage analysis for each individual competence in using English was quite difficult by virtue of large number of students in the class. The curriculum adopted and implemented by Indonesian schools, K13 curriculum, also assigned teachers with lots of tasks other than merely conducting interlanguage analysis, and those tasks required focus and preparation to accomplish which automatically consumed time possessed by the teachers:

"As assigned by the curriculum, I also have to describe every student's progress on character perspective into my portfolio. This perspective is the paradigm of the curriculum adopted by the school where I am teaching" (Teacher 8).

This condition naturally constrained the teachers to regularly manage to do interlanguage analysis towards each student's English competence inasmuch as the time owned by the teachers was limited. 


\section{Cognitive Category}

All participants also shared their positive cognition towards doing interlanguage analysis in relation to its potential contribution to further English instructions.

\section{Potential contribution of Interlanguage Analysi}

All participants also shared their positive cognition towards doing interlanguage analysis because it was potential to contribute on further teaching. It was considered really potential since it could become the basis of investigating students' current competence in English, contextual and meaningful English interlanguage that students owned, and their difficulties in using English. One of the participants mentioned: "I need to do interlanguage analysis to teach meaningfully and contextually based on my students' needs and competence" (Teacher 2).

In addition, it could also be the basis of developing contextual learning materials in accordance with students' needs, developing learning media which accommodate their interests, planning teaching strategies which are suitable for their competence and needs, and preparing more meaningful and effective teaching for them. Another participant emphasized: "basically I am triggered to be creative after doing interlanguage analysis because I can prepare good learning materials, teaching strategies, media relevant to my students' interest, and overall effective teaching" (Teacher 3). To sum up, all participants shared positive cognition concerning with doing interlanguage analysis which was in line and connected to one another.

\section{CONCLUSION}

Based on the findings of this study, it can be concluded that all participants affectively share their positive attitudes towards doing interlanguage analysis inasmuch as they are eager to provide competence-based instruction and get teaching reflection. From the aspect of behavior, all participants also have positive attitudes towards conducting interlanguage analysis despite several constraints. They have agreement that interlanguage analysis can possibly be carried out while giving assessment and exercise, but in accordance with time availability. Interlanguage analysis is also able to be done with utilizing useful media in spite of several challenges such as limited knowledge and understanding for analyzing sociolinguistics competence, limitation of students' English output, large number of students, and other tasks assigned by the curriculum.

Cognitively, all participants also have in-line positive attitudes towards undertaking intelanguage analysis because it is potential to contribute on interpreting students' current competence, developing learning materials, developing learning media, planning teaching strategies, and preparing meaningful and contextual further instructions. 
This study is considered really essential to be one of the resources for English teachers in improving the continuity of English teaching since English teachers must play their role as a facilitator. Furthermore, to capably facilitate students, the teachers should plan and design further instructions which are relevant to students' needs on the basis of their communicative competence. Accordingly, interlanguage analysis is crucial to be conducted inasmuch as its result takes place as the basis of considerations for preparing more effective, contextual and meaningful instructions.

\section{ACKNOWLEDGEMENT}

I would like to take this chance to express my sincere gratitude to my colleagues, some Indonesian English teachers who kindly and professionally contributed as the participants of this study, and who kindly kept supporting the completeness of this study.

\section{REFERENCES}

Abedi, J., \& Linquanti, R. (2012). Issues and Opportunities in Improving the Quality of Large Scale Assessment Systems for English language learners. Stanford University, Understanding Language Conference.

Adjemian, C. (1976). On the Nature of Interlanguage System, Language Learning. 26: 297-320.

Ajzen, I., \& Fishbein, M., (1977). Attitude-behavior Relations: A Theoretical Analysis and Review of Empirical Research. Psychological bulletin, 84(5), pp.888-918.

Alvarez, L., et al. (2014). Focusing Formative Assessment on the Needs of English Language Learners. WestEd on the topic of formative assessment, Wested.org.

Bachman, L. F., \& Palmer, A. S. (1996). Language Testing in Practice: Designing and Developing Useful Language Tests. Oxford etc.: OUP.

Baron, R.A. \& Byrne, D., (1984). Social psychology understanding human interaction, Boston: Allyn \& Bacon.

Brown, H. D. (2004). Language Assessment: Principles and Classroom Practice. New York, Longman.

Calder, B., \& Lutz, R. (1972). An Investigation of Some Alternatives to the Linear Attitude Model. In M. Venkatesan, ed. Proceedings. Third Annual Conference of the Association for Consumer Research. Chicago, IL: Association for Consumer Research, pp. 812-815.

Canale, M. (1983). From Communicative Competence to Communicative Language Pedagogy. In Richards, J. C., \& Schmidt, R. W. (Eds.), Language and Communication, 2-27. London: Longman.

Canale, M., \& Swain, M. (1980). Theoretical Bases of Communicative Approaches to Second Language Teaching and Testing. Applied Linguistics,1, 1-47.

Common European Framework of Reference for Languages: Learning, Teaching, Assessment. 2001. Council of Europe [online]. http://www.coe.int/t/dg4/linguistic/Source/Framework_EN.pdf. (12 January, 2014).

Corder, S. P. (1967). Describing the Language Learner's Language. ERIC, ED 054-696, 1971, pp. 57-64. 
Eagly, A. H., \& Chaiken, S. (1998). Attitude structure and function. In D. Gilbert, S. T. Fiske, \& G. Lindsey (Eds.), Handbook of social psychology (Vol. 2, pp. 269-322). Boston: McGraw-Hill.

Ellis, R. (2004). Classroom Second Language Development. Oxford, Pergamon.

Fang. X., \& Xue-mei. J. (2007). Error Analysis and the EFL Classroom Teaching. US-China Education Review, ISSN1548-6613, USA.

Fishbein, M. (1963). An Investigation of the Relationships between Beliefs about an Object and the Attitude toward that Object. Human Relations, 16, pp.233-240.

Fisiak, J. (ed) (1981). Contrastive Linguistics and the Language Teacher. New York, Pergamon Press.

Frith. B. M. (1978). Interlanguage Theory: Implication for the Classroom. The Modern Language Journal. 81, 285-300.

Genesee, F. \& Geva, E. (2006). Chapter 7: Cross-linguistic relationships in working memory, phonological processes, and oral language, In: D. August \& T. Shanahan, Developing literacy in second language learners. Report of the National Literacy Panel on MinorityLanguage Children and Youth, Mahwah: Lawrence Erlbaum, pp. 175-184.

Greenwald. M. (2013). National Standards for Language Learning and 21st Century Skills for World Languages. SANS Inc.10 White Wood Lane North Branford, CT 06471.

Hymes, D. H. (1972). On Communicative Competence. In Pride, J. B., \& Holmes, J. (Eds.), Sociolinguistics, 269-293. Baltimore, USA: Penguin Education, Penguin Books Ltd.

IEAB. (2007). International Education Advisory Board (Learning in the 21st Century: Teaching Today's Students on Their Terms).

Ioannou-Georgiou, S., \& Pavlou, P. (2003). Assessing young learners. Oxford: Oxford University Press.

James. C. (1998). Errors in Language Learning and Use: Exploring Error Analysis. London: Longman

Lado. R. (1957). Linguistics Across Cultures. Michigan: University of Michigan Press.

Malhotra, N.K., (2005). Attitude and affect: new frontiers of research in the 21st century. Journal of Business Research, 58(4), pp.477-482.

Mizuno. H. (1988). Interlanguage Analysis for Foreign Language Teaching. Journal of Psychology \& Education. Kanagawa University. Japan

Nemser, W. (1969). Approximative Systems of Foreign Language Learners. IRAL 9: 115-224.

P21. (2011). 21st Century Skills Map: Designed in Cooperation with the Nation's World Language Educators, Partnership for 21st Century Skills.

Pallotti, G., \& Peloso, A. (2008). Acquisition sequences and definition of linguistic categories. The Open Applied Linguistics Journal, 1, 77-89.

Rea-Dickins, P. (2001). Mirror, mirror on the wall: Identifying processes in classroom assessment. Language Testing, 18(4), 428-462.

Rosenberg, M.J., (1956). Cognitive structure and attitudinal affect. The Journal of Abnormal and Social Psychology, 53(3), pp.367-372.

Ryan. L. (2012). Students' Attitudes towards Corrective Feedback in the Second Language Classroom. Ireland, Trinity College. University of Dublin.

Savignon, S. J. (1972). Communicative Competence: An Experiment in Foreign- Language Teaching. Philadelphia: The Centre for Curriculum Development, Inc.

Savignon, S. J. (1983). Communicative Competence: Theory and Classroom Practice. Texts and Contexts in Second Language Learning. Reading, Massachusetts at all: Addison-Wesley Publishing Company.

Saville-Troike, M. (2006). Introducing Second Language Acquisition, Cambridge : C. U. P. 
Schulz. R. A. (1996). Focus on Form in the Foreign Language Classroom: Students' and Teachers' Views on Error Correction and the Role of Grammar, American Counsil of the Teachingo of Foreign Language. DOI: 10.1111/j.1944-9720.1996.tb01247.x

Selinker, L. Interlanguage. IRAL 10 (1972): 209-23l.

Selinker. L. (1988). Papers in Interlanguage. Occasional Papers No. 44, Singapore. SEAMEO Regional Language Center.

Sharwood. S., \& Michael. (1994). Second Language Learning. Theoretical Foundation. London. Longman

Skehan, P. (1995). Analysability, Accessibility, and Ability for us. In G. Cook and B. Seidlhofer, eds. Principle and Practice in Applied Linguistics. Oxford, Oxford University Press.

Spooncer, F., (1992). Behavioural studies for marketing and business, Leckhampton, UK: Stanley Thornes.

Tarone. E. (2006). Interlanguage. Elsevier Ltd.

Tomczyk. E. (2013). Perceptions of Oral Errors and Their Corrective Feedback: Teachers vs. Students. Journal of Language Teaching and Research, Vol. 4, No. 5, pp. 924-931. (C) 2013 ACADEMY PUBLISHER Manufactured in Finland. ISSN 1798-4769. doi:10.4304/jltr.4.5.924-931

Valdez Pierce, L., \& O’Malley, J. M. (1992). Performance and portfolio assessment for language minority students. NCBE Program Information Guide Series, 9, Spring.

Wardaugh. Ronald. (1970), The Contrastive Analysis Hypothesis. TESOL Quarterly, 4/2: 140-148.

Widdowson, H. G. (1983). Learning Purpose and Language Use. Oxford, Oxford University Press.

Yip, V. (1995). Interlanguage and learnability from Chinese to English. Amsterdam, John Benjamin B.V. 